\title{
Fetal Tachycardia
}

National Cancer Institute

\section{Source}

National Cancer Institute. Fetal Tachycardia. NCI Thesaurus. Code C92796.

A fetal heart rate above $160 \mathrm{bpm}$ that is sustained for longer than 10 minutes. 